\title{
Editorial
}

\section{Climate change: a call to action Introduction}

On December 15, 2018, in the town of Katowice, Poland, diplomats from 200 countries adopted a detailed set of rules to uphold and implement the Paris Agreement, the international treaty drafted by United Nations Framework Convention on Climate Change to reduce greenhouse gas emissions. This deal will require every country to track its emissions and climate policies by following a uniform set of standards. Furthermore, countries are to cut their emissions ahead of the next round of talks in 2020. Climate change is a complicated problem, one that will not be solved by national governments alone. A lot of real action is going to come from the entrepreneurs, the business sector, at the city and state level (Plumer, 2018b).

In this editorial, we discuss the latest Intergovernmental Panel on Climate Change (IPCC) report, the follow-up National Climate Assessment (NCA) report and the effects detailed in these reports. Then, we discuss what might some of the remediation steps be. Where do we go from here? What are actionable steps that can be taken at the policy level, at the corporate level and at the individual level?

\section{IPCC reports and predictions}

On October 8, 2018, the latest report from the United Nations scientific panel was published in Incheon, South Korea. This IPCC report portends a far gloomier picture of climate change consequences than previously held and states that avoiding this damage requires transforming the world economy at a speed and scale that has "no documented historic precedent." According to this latest IPCC report released, if the greenhouse gas emissions continue at the present level, the atmosphere will warm by $2.7^{\circ} \mathrm{F}$ or $1.5^{\circ} \mathrm{C}$ above pre-industrial levels by 2040. This updated threshold is lower than the previously held threshold of $3.6^{\circ} \mathrm{F}$ or $2^{\circ} \mathrm{C}$ (Davenport, 2018).

The IPCC, founded in 1988, is a body governed by the United Nations and its primary charge is to evaluate climate change science. The IPCC is comprised of hundreds of scientists and volunteers who assess the research on climate change and synthesize it into major assessment reports every five to seven years. The IPCC review process assesses peer-reviewed scientific literature, which is the majority, almost 90 percent, but it also considers some "gray literature," non-peer-reviewed material. The working groups of the IPCC draft three assessments or volumes. Working Group 1 analyzes the scientific evidence for climate change and the extent to which human activity is the cause for this change. Working Group 2 concentrates on the impacts of climate change and how animals, humans and plants can adapt. Working Group 3 focuses on climate mitigation, on how the climate impact can be reduced. The academic experts are recommended by governments and NGOs and the final list of experts is selected by the coordinating body of the organization. Other than travel expenses, these scientists are not compensated (Clark and Brief, 2011). So, one can assume that the scientific reports are unbiased and not influenced by any agency with a particular agenda.

Management Decision Vol. 57 No. 9, 2019 pp. $2612-2620$ (C) Emerald Publishing Limited 0025-1747 DOI 10.1108/MD-09-2019-023

\section{Results of the IPCC report}

The most dramatic finding of the IPCC report is that we have only 12 years to be kept to a maximum of $1.5^{\circ} \mathrm{C}$ and avoid catastrophic environmental breakdown. The other finding is 
that the impact and costs of the temperature rise will be much greater than expected. The report calls for urgent and unprecedented changes to be implemented to reach this target, which is on the ambitious side of the Paris Agreement pledge to keep temperatures between 1.5 and $2^{\circ} \mathrm{C}$ (Taylor et al., 2018).

As per the Paris Agreement, most nations agreed to keep global temperatures well below $3.6^{\circ} \mathrm{F}\left(2^{\circ} \mathrm{C}\right)$. However, the current pledges to cut carbon emissions would push global warming to at least $5.4^{\circ} \mathrm{F}\left(3^{\circ} \mathrm{C}\right)$ by 2100 . This temperature rise would risk natural tipping points, such as the permafrost melting that would subsequently release tons of methane into the atmosphere, which, in turn, would further drive global temperatures higher. In the past decade, the world has witnessed a slew of record breaking storms, droughts, forest fires, coral bleaching, heat waves and floods with just $1.8^{\circ} \mathrm{F}\left(1^{\circ} \mathrm{C}\right)$ change. However, all of these climate-related events will get much worse with $3.6^{\circ} \mathrm{F}\left(2^{\circ} \mathrm{C}\right)$ (Leahy, 2018).

The IPCC report notes that global warming needs to be limited from 2 to $1.5^{\circ} \mathrm{C}$. This is important because a reduction would reduce the challenging impacts such as heat waves, rising seas, erratic weather, stronger storms and subsequent secondary impacts on infrastructure and migration patterns (Leahy, 2018). With the lower limit, the likelihood of Artic Ocean free of ice in Summer would be once a century vs once a decade with higher temperature rise. With the lower limit, coral reefs would decline by 70-90 percent vs most coral reefs would be destroyed with higher temperature rise. Sea levels rise would also be $10 \mathrm{~cm}$ lower with the lower temperature rise. In addition, adapting to $1.5^{\circ} \mathrm{C}$ warming would be easier and less expensive. However, the reality is that even limiting warming to $1.5^{\circ} \mathrm{C}$ would require unprecedented changes that are twofold: the world needs to start cutting emissions and these cuts need to happen very soon (Rathi, 2018).

In order to avoid the ramifications of climate change, it would require a transformation of the world economy. The damage of climate change is estimated at $\$ 54 \mathrm{tn}$ by the IPCC report. Even though it is possible to technically achieve the rapid changes needed to avoid the $2.7^{\circ}$ of warming, such solutions are likely to be politically infeasible (Davenport, 2018).

\section{NCA report}

A month after the IPCC report, another report was released. Issued by 13 federal agencies, this report warns of the consequences of climate change for the USA and outlines the crippling effects of a changing climate that include the wildfires in California, the crop failures in Midwest and the crumbling infrastructure in the South. The report estimates that climate change could slash up-to a tenth of gross domestic product by 2010, which is more than double the losses of the Great Recession. The price tags put forth by the report include: $\$ 141 \mathrm{bn}$ from heat-related deaths, $\$ 118 \mathrm{bn}$ from sea level rise and $\$ 32 \mathrm{bn}$ from infrastructure damage (Davenport and Pierre-Louis, 2018).

A hotter climate will lead to more heat waves and related deaths and more outbreaks of diseases. The two areas of impact that will be of particular interest are agriculture and trade.

\section{Agricultural risks}

The hardest hit region will be the farm belt where by 2050 changes in rainfall and hotter temperatures will reduce the agricultural productivity of the Midwest to 1980s levels. According to the report, rising temperatures, extreme drought, wildfires on rangelands and heavy downpours will disrupt agricultural productivity. These risks also depend on the adaptability of the farmers. For examples, farmers who practice conservation practices fared better in the 2012 Midwestern drought. However, the federal programs that were designed to help farmers with climate change have stalled with the expiration of the farm bill this Fall (Davenport and Pierre-Louis, 2018). 
Extreme weather will also impact US trade and economy since weather-related disasters will temporarily shut factories in the USA and abroad that, in turn, would cause price spikes. A large portion of the American companies supply chains are global and, hence, there is no industry that would be immune from effects of climate change. As an example, during the extreme flooding in Thailand in 2011, Western Digital, an American company with majority of operations in Thailand, sustained $\$ 199 \mathrm{~m}$ in losses and had to cut its hard drive shipments by half. This shortage led to a doubling of price of hard drives that affected companies such as Apple, HP and Dell (Davenport and Pierre-Louis, 2018).

What will the USA need to do in order to get prepared to address global warming concerns? Besides the mitigation strategy of cutting emissions drastically, there are other adaptation strategies. In the case of agriculture, extremely hot temperature and droughts reduce crop yields and water supplies for irrigation. As a solution, more precise irrigation techniques would be required to conserve water in areas of drought. New crop varieties ought to be developed that can tolerate drought, heat and pests. Detailed weather forecasts can help farmers determine what crops to plan and when. Engineers need to adjust infrastructure planning to incorporate the new realities of climate change. Examples include adjusting sewer systems to accommodate heavier rainfalls, relocating neighborhoods in low lying, flood prone areas (Plumer, 2018a).

Since the projections for sea level rise range from 1 to 4 feet this century, large cities with coastlines like New York City and Miami will probably invest in sea walls and tide gates. Smaller coastal communities have fewer options and millions of residents might need to relocate inland. Flood insurance policies might have to be adjusted to discourage residents from building in disaster prone areas. Natural environment can also be managed to defend against climate change. Examples include planting more trees to absorb excess carbon dioxide and reduce urban temperatures, restoring wetlands and marshes to protect cities and coasts from flooding, controlled fires in forests to protect against wildfires and protecting pollinator species to improve the resiliency of agricultural systems (Plumer, 2018a).

In essence, the NCA report cautions that government officials need to include climate change in their decision making and ought to conduct and update contingency plans. It also emphasizes that the outcomes depend on how quickly the USA and other countries take action to mitigate global warming (Plumer, 2018a).

\section{What can we do? How can we respond? Tools and strategies}

Given all this information on the implications of global climate change and warming, what can be done? What is the call of action here to address one of the biggest global challenges of the modern world. The solutions range from policy decisions by government and regulators to actions at the business level to individual and consumer choices.

\section{Role of governments and policy prescriptions}

As the world demand for sustainable products, services and systems rises, there is a crucial role for governments in facilitating the transition to an economy that is much more efficient, much more fair and much less damaging than the present one. Governments that lead will be in a stronger position to set the agenda and establish advanced positions for their industries and their citizens. Countries that lag behind will inevitably face increasing competitive disadvantage and lost opportunity (Peck and Gibson, 2002).

In the USA and Canada, as in most other developed countries, the government is the largest landowner; the largest fleet owner; the largest single employer; and the largest landlord or operator of buildings. Therefore, it is also the largest consumer of energy, the largest producer of most environmental impacts, the greatest single source of support for social capital and so on. A strong case can be made that governments should "walk the talk" by 
putting their internal operations on a firm sustainability foundation (Bell, 2002). In developing countries, the role of the government assumes even greater significance. In relation to sustainability issues, the government's role is to encourage private enterprise to address the needs of the world's entire population (i.e. not just those fortunate enough to live in rich market economies) and to do so through a sustainability lens (Prahalad and Hart, 2002).

What are the various policy prescriptions that can be utilized by governments or regulatory agencies trying to curb emissions? The three main solutions put forth by the NCA report are: put a price on greenhouse gas emissions, either in form of taxes or fees, establish government regulations on pollution levels and invest public money on clean energy research (Davenport and Pierre-Louis, 2018).

\section{Pricing carbon or carbon taxes}

What is a carbon tax? The basic economic theory has to do with externalities that occur as a side effect of industrial or commercial activity which causes an impact on third parties. From this perspective, the emissions in the atmosphere are a negative externality, on which economists propose putting a price so as to internalize the externality. The IPCC climate report states that a price on carbon is central to prompt mitigation. In order for it to be effective, such a price would have to range from $\$ 135$ to $\$ 5,500$ per ton of carbon dioxide pollution in 2030 , and from $\$ 690$ to $\$ 27,000$ per ton by 2100 (Davenport, 2018). As a comparison, under the Obama administration, the price of carbon was estimated at $\$ 50$ per ton and this figure was lowered to about $\$ 7$ per ton under the Trump administration.

Although a carbon tax sounds good theoretically, it would be very difficult to implement it in reality. As shown by the recent Yellow Vest protests in France, the carbon tax was met with a stiff resistance from the public. The high price estimate put forth by the reports would make it all the more difficult to implement. A carbon tax might work if it is designed more holistically. As an option, the revenues of the tax might be diverted to relieve the burden on the working class or toward the development of renewable energy. However, designing and implementing the carbon tax would require the support of the public and the political will of the leaders.

\section{Government regulations}

Regulations are needed to establish a standard or threshold for natural resources, like air and water, or for industry, such as efficiency regulations imposed on vehicles (Gillis, 2018). Another policy proposal graining traction is to set up a national clean energy standard which would require that a certain share of electricity generation be derived from low-carbon sources. This policy would require the share of electricity from low emitting sources to increase steadily over time. The standard would give states the flexibility in how they meet the national goal by choosing which energy sources to adopt. Such a policy would also encourage the growth of renewable energy and encourage investment in other options to clean the power grid (Gillis and McBride, 2018).

\section{Investment in public projects/clean energy projects}

If governments want to discourage consumers from driving, it needs to provide alternatives to get to work. Most of American public does not have access to public transit and the ones that do exist in cities like New York City and Chicago need upgrades (Gillis, 2018). The USA needs to invest in public infrastructure and clean energy projects. From the literature in resource economics, the Hartwick Rule calls to rent non-renewables and re-invest the revenue toward the development of clean, renewable energy (Hartwick, 1977). As an example, the revenues from petroleum could potentially be re-invested in solar or wind energy technology. 


\section{Corporate responses}

Of the world's 100 largest economic entities, 63 are corporations, not countries. This immense power calls for greater responsibility as society wants to hold global businesses accountable to meet the challenges facing our planet. The world is witnessing increasing limits on growth and lesser credit. For this reason, companies need to develop and execute a strategy for emissions reductions and sustainability. In a large picture, a sustainable business means a business that can thrive in the long term. Sustainability is much more than a public relations push or efforts at greenwashing, focusing more on communicating green efforts than on the efforts themselves. Sustainability is even bigger than an occasional agreement to ongoing efforts to save the planet. If sustainability is to be realized fully and well implemented, it can drive a bottom-line strategy to save costs, a top-line strategy to reach a new consumer base and a talent strategy to get, keep and develop creative employees. This kind of true sustainability has four equal components:

(1) Social: to address conditions that affect us all, including poverty, violence, injustice, education, public health, and labor and human rights.

(2) Economic: to help people and businesses meet their economic needs; for people: securing food, water, shelter and creature comforts; for businesses: turning a profit.

(3) Environmental: to protect and restore the earth - for example, by controlling climate change, preserving natural resources and preventing waste.

(4) Cultural: to protect and value the diversity through which communities manifest their identity and cultivate traditions across generations (McKinsey Quarterly, 2009).

In the absence of national legislation in the USA, most of the corporate responses come in the form of corporate social responsibility (CSR), a voluntary effort for corporations to behave responsibly and pursue sustainable development goals. Hence, in very general terms, CSR stands for the social role or responsibility that a corporation has toward the society that it operates within.

CSR is located at the intersection of business and society. Its role changes as demands and the expectations of society change. The CSR movement has had four main phases over the last 15 years. It started with a reactive phase, wherein CSR was viewed as a public relations function intended for damage control when companies made mistakes with the community and the environment. In the second phase, some of these companies started to incorporate process efficiencies in manufacturing and services and started to establish relationships with stakeholders including NGOs. In the third phase of integration, companies created key performance indicators that were then used to publicly report on various functional business units. The knowledge garnered from this stage fed into the fourth stage of value creation where brand enhancement, product development and R\&D looked for solutions to social issues that impacted the bottom line as well (Smalheiser, 2006). The main advantage of a well-executed CSR is that it builds business value in many ways: by enhancing brand image, establishing a co-operative relationship with government or regulatory agencies and attracting investors who are interested in sustainability. In addition, a company can attract and retain motivated employees, enter new markets, position the company as good partner for peers, governments and NGOs, and improve risk recognition and avoidance (Smalheiser, 2006).

Reporting, once considered voluntary, is now becoming a de facto requirement for most companies that are concerned about their public image. Fortunately, there are numerous standards that exist for companies to choose from - ranging from international standards such as Global Reporting Initiative, International Organization on Standardization (ISO 14001), Carbon Disclosure Project, to smaller, local standards such Dow Jones Sustainability Index and Ceres. In order to illustrate gains in environmental performance, a company needs to be able to 
report and verify its accomplishments. In this age of media scrutiny and consumer backlash, to not do so would invite criticisms of greenwash that, in turn, would undermine any efforts made by the organization.

\section{Role of individuals/consumers}

The average US citizen consumes 18 tons of natural resources per person per year and generates an even higher volume of wastes. The affluent consumers in developed economies are inundated by consumer options, most of which are produced with considerable carbon footprints. The poorer people, who are responsible for emitting the lowest levels of greenhouse gases, are disproportionately vulnerable to the loss of biodiversity and ecosystem services. Furthermore, they will also suffer most from the impacts of climate change, such as flooding, reduced access to clean freshwater, health and social problems (SCORE!, 2008).

According to the One Planet Business Report, food and drink have the highest levels of ecological impact per dollar spent, followed by household equipment and housing. Each $\$ 1 \mathrm{~m}$ spent by consumers on food has an ecological footprint of approximately 1,500 hectares. In terms of absolute consumption impacts, food, transport and housing are seen as the most significant (WWF-UK, 2006).

How can consumers make more informed and more sustainable choices in these primary areas of impact? The main takeaway is that consumers need to change their lifestyles and consumption patterns to more sustainable alternatives. This is especially true in the areas where the consumers have control, such as dietary preferences, modes of transportation and the buildings they reside in (MacIntosh, 2018).

\section{Food and diet}

The best option is to eat lower on the food chain and buy food from local community-supported agriculture farm shares. A simple choice of eating less meat would in turn led to an overhaul of agricultural and land-use practices, including protection of forests and not converting forests into farms for livestock. The livestock sector alone accounts for 14.5 percent of the greenhouse gas emissions, that is more than the transport sector (MacIntosh, 2018). Another option is to eat organic food since it is grown without the use of synthetic pesticides, fertilizers, antibiotics or added hormones.

\section{Water}

There has been much discussion on the environmental damage from bottled water. First of all, the water inside is not regulated as much as tap water and there is no guarantee where this water was collected. In addition, bottled water contains a host of issues. The flexible plastic water bottles leach phthalates, chemicals that mimic female hormone estrogen and are linked to health problems. The most damaging environmental concern comes from the manufacture of $1.5 \mathrm{~m}$ plastic bottles (from petrochemicals) every year and most of these bottles end up in landfills (Horn, 2006). A sustainable solution is filtered water and there are numerous water filters in the market ranging from simple carbon filters and faucet mounted filters to expensive systems like reverse-osmosis systems and ultraviolet light filters.

\section{Buildings}

Residents can increase the home's efficiency by sealing cracks around doors and windows, turning down the thermostat by $2^{\circ}$, replacing the lightbulbs with compact fluorescent lightbulbs, using smart thermostats that switch on when residents are in the home and upgrading to more energy-efficient appliances. Suburban homes with a yard are heavy on water and pesticide consumption and one adaptation strategy is to employ Xeriscape 
$\mathrm{MD}$

57,9

landscaping, that is designed for areas that are susceptible to drought. Other simple strategies to reduce energy consumption include installing a fan to cool the house, washing clothes in cold water cycles, drying clothes on drying rack or clothesline, using power strips that are turned off when not in use (Garlough et al., 2008).

\section{Transport}

Consumers need to travel less and shift toward more sustainable modes of transport. If available, consumers can choose to take public transportation such as buses and trains instead of driving to work and dealing with congested pathways. In case public transportation is not a viable option, consumers would need to more sustainable alternatives such as ride sharing or moving toward electric and hybrid cars (MacIntosh, 2018).

\section{Going forward}

At the UN Climate Meeting in Poland, about 200 leaders met to agree on rules on how to meet their national promises to reduce greenhouse gas emissions under the Paris Climate Agreement of 2015. Although the Trump administration has stated its intention to back out of the Paris Agreement, a coalition comprised of governors, mayors and local officials from the USA stated their commitment to reducing greenhouse gases and met with governments from France, Germany and others (Hersher, 2018).

The US Climate Alliance is a coalition of states that have promised to abide by the Paris Agreement on Climate Change and is made up of 14 Democratic senators and 3 Republican senators from traditional blue states. This coalition was created after President Trump's announcement that USA will withdraw from the Paris Agreement. Included in this coalition was the Mayor of Pittsburg, Bill Peduto, who has pledged to transition the city governments energy use to entirely renewable sources by 2030. It is the largest coalition to emerge since Trump took office: the 16 states represent 40 percent of US population and half of its GDP. However, the 16 states only represent a quarter of US emissions (Meyer, 2018a).

Some of the other leaders of American cities are increasingly involved in climate policy. Los Angeles is publicly tracking its greenhouse emissions and is spending more than $\$ 100 \mathrm{bn}$ to expand its train system. Houston's mayor is working on a plan to make the city carbon neutral by 2050 (Hersher, 2018). Indeed, the mayor of CA, Jerry Brown, warns that governments are not being ambitious enough about moving to a renewable energy economy.

\section{Green New Deal}

One of the policies being proposed by recently elected Democrats is the Green New Deal, the goal of which is to come up with a "detailed national, industrial, economic mobilization plan" to rapidly transition the country away from fossil fuels and toward clean energy, such as solar, wind and electric cars (Friedman, 2019). In essence, this Green New Deal aims to cut US emissions fast enough to reach the climate goal put forth by the Paris Agreement: preventing warming to no more than $2.7^{\circ}$ by 2100 .

The Green New Deal is comprehensive and ambitious. It was pushed forth by The Sunrise Movement, a youth-led activism group that has listed seven demands that any Green New Deal must address. These demands range from requiring the USA to get all of its energy from renewables to decarbonizing, repairing and improving transportation and infrastructure to investment in technologies to capture and remove carbon dioxide from the atmosphere. The most controversial aspect of this Green New Deal is the proposed job guarantee, in that every American can have a job within this new economy. For now, the Green New Deal is being promoted by Ocasio-Cortez, the youngest woman elected to Congress who grew up with stagnating climate policies in the USA (Meyer, 2018b). In order for the Green New Deal to gain political traction, it needs larger acceptance by Liberals and 
Conservatives alike. One idea suggested is to invest a portion of each dollar raised by a carbon tax in two new community colleges and high-speed broadband in rural areas of every state. In other words, for the Green New Deal to work, every American needs to feel a chance to gain from it (Friedman, 2019).

\section{Conclusion}

We are witnessing climate change on a widespread, global scale. From the bleaching of corals in Australia to ferocious forest fires in California, no nation state is immune to climate change. Indeed, the two scientific reports that were published in the end of 2018 laid out the ramifications of continued warming and the devastating effects these would have all across the world.

The response to climate change needs to be multi-pronged. Governments and regulatory agencies need to align public policy and investments that favor clean, renewable energy and weans away from heavy polluting industries. Corporations and businesses ought to invest in natural capital, to preserve natural resources and align their reporting to reflect their social and environmental impacts. Individuals and consumers should reflect upon their personal consumption choices and the impact of these choices on the natural resources and the climate.

The issue of climate change is enormous, non-linear and dynamic. Indeed, climate change is perceived to be a complicated and unsolvable problem. The Earth is resilient and it might survive our species. However, the future of humanity, in another 50 or 100 years, depends directly on the choices we make and implement today.

\section{Kathy Dhanda}

\section{References}

Bell, D.V.J. (2002), "The role of government in advancing corporate sustainability", background paper, York University, available at: www.irisyorku.ca/.../file_the_role_of_government_in_ advancing_corporate_sustainability.pdf (accessed February 2011).

Clark, D. and Brief, C. (2011), "What is the IPCC?", The Guardian, December 6, available at: www. theguardian.com/environment/2011/dec/06/what-is-ipcc (accessed November 2018).

Davenport, C. (2018), "Major Climate Report describes a strong risk of crises as early as 2040", The New York Times, October 7, available at: www.nytimes.com/2018/10/07/climate/ipcc-climatereport-2040.html

Davenport, C. and Pierre-Louis, K. (2018), "US Climate Report warns of damaged environment and shrinking economy”, The New York Times, November 23, available at: www.nytimes.com/2018/ 11/23/climate/us-climate-report.html?module=inline

Friedman, T. (2019), “The Green New Deal rises again”, The New York Times, January 8, available at: www.nytimes.com/2019/01/08/opinion/green-new-deal.html

Garlough, D., Gordon, W. and Bauer, S. (2008), Green Guide: The Complete Reference for Consuming Wisely, National Geographic Society, Washington, DC.

Gillis, J. (2018), "Forget the carbon tax for now", The New York Times, December 27, available at: www. nytimes.com/2018/12/27/opinion/carbon-tax-climate-change.html

Gillis, J. and McBride, J. (2018), "Here's how to cut emissions without taxing them", The New York Times, August 14, available at: www.nytimes.com/2018/08/14/opinion/how-to-cut-greenhousegas-emissions-without-taxing-them.html

Hartwick, J. (1977), "Intergenerational equity and the investing of rents from exhaustible resources", American Economic Review, Vol. 66, pp. 972-974.

Hersher, R. (2018), "Mayors and governors rebut Trump administration position at Climate Summit", National Public Radio, December 12, available at: www.npr.org/2018/12/12/676001283/mayorsand-governors-rebut-trump-administration-position-at-climate-summit 
Horn, G. (2006), Living Green: A Practical Guide to Simple Sustainability, Freedom Press, Topanga, CA.

Leahy, P. (2018), "Climate change impacts worse than expected", National Geographic, October 7, available at: www.nationalgeographic.com/environment/2018/10/ipcc-report-climate-changeimpacts-forests-emissions/

McKinsey Quarterly (2009), "When sustainability means more than green”, article summary of the book "Strategy for Sustainability: A Business Manifesto" by Werbach, Adam, No. 4, pp. 74-79.

MacIntosh, E. (2018), "What the new report on climate change expects from you?", CNN, October 8, available at: www.cnn.com/2018/10/08/world/ipcc-climate-change-consumer-actions-intl/index. html?utm_medium $=$ social\&utm_term $=$ link\&utm_source $=$ fbCNN\&utm_content $=2018-10$ $14 \mathrm{~T} 10 \% 3 \mathrm{~A} 29 \% 3 \mathrm{~A} 01$

Meyer, R. (2018a), "17 Bipartisan governors vow to fight climate change - and President Trump", The Atlantic, September 13, available at: www.theatlantic.com/science/archive/2018/09/17-statesvow-to-fight-climate-change-with-new-policies/570172/

Meyer, R. (2018b), "The Democratic Party wants to make climate policy exciting", The Atlantic, December 5, available at: www.theatlantic.com/science/archive/2018/12/ocasio-cortez-greennew-deal-winning-climate-strategy/576514/

Peck, S. and Gibson, R. (2002), "Pushing the revolution", Alternatives Journal, Vol. 26 No. 1.

Plumer, B. (2018a), "Five Big ways the United States will need to adapt to climate change", The New York Times, November 26, available at: www.nytimes.com/2018/11/26/climate/adaptation-usclimate-change.html

Plumer, B. (2018b), "Climate negotiators reach an overtime deal to keep paris pact alive", The New York Times, December 15, available at: www.nytimes.com/2018/12/15/climate/cop24-katowiceclimate-summit.html

Prahalad, C.K. and Hart, S.L. (2002), "The fortune at the bottom of the pyramid”, Strategy+Business, First Quarter, available at: www.cs.berkeley.edu/\%7Ebrewer/ict4b/Fortune-BoP.pdf (accessed March 2011).

Rathi, A. (2018), "Everything you need to know about the new 1.5 degree Celsius climate-change report", Quartz, October 7, avialable at: https:/qz.com/1416250/everything-you-need-to-knowabout-the-new-1-5c-climate-change-report/

SCORE! (2008), System Innovation for Sustainability 1: Perspectives on Radical Changes to Sustainable Consumption and Production, Sustainable Consumption Research Exchanges (SCORE!).

Smalheiser, K. (2006), "Value driven leadership: responsible companies committed to tackling global societal woes have discovered they gain strategic advantage", Special Advertising Feature, November 13, pp. S1-S10, available at: www.fortune.com/sections; www.timeincnewsgroupcustompub.com/ sections/061113_CSRv2.pdf

Taylor, M., Weaver, M. and Davidson, H. (2018), "IPCC Climate Change Report calls for urgent action to phase out fossil fuels - as it happened", The Guardian, October 8, available at: www.theguardian. com/environment/live/2018/oct/08/ipcc-climate-change-report-urgent-action-fossil-fuels-live

WWF-UK (2006), "One Planet Business". 